\title{
A Model of Waste Management Improvement in Indonesia
}

\author{
Yefta Andi Kus Noegroho', Suzy Noviyanti², Jony Oktavian Haryanto ${ }^{3}$, \\ and Lanita Winata ${ }^{4}$ \\ Faculty of Economics and Business, Satya Wacana Christian University ${ }^{1,2}$ \\ Faculty of Economics and Business, President University ${ }^{3}$ \\ Faculty of Economics and Business, Griffith University Australia ${ }^{4}$ \\ Email: yefta.noegroho@gmail.com
}

\begin{abstract}
Waste management (garbage) is an important thing and cannot be negotiated by any companies. By applying a good waste management system, companies will be the companies that are pro-environment and they will be positively appreciated by their stakeholders. This study aims to examined the factors that influence the waste management and their impacts on the financial performance of the company through a model to determine the antecedents of commitment and waste management program that eventually lead to improve financial performance. This research was conducted by distributing questionnaires to 100 managers of companies that implement waste management programs. The results showed that there was a positive influence of awareness and legal compliance towards its environmental commitments and positive influence on the environmental commitment program of waste management and waste management programs towards the financial performance of the company. The waste management program could make the companies prepare their operation better and minimize their environment cost. This study also gives a boost to companies that wants to improve the company's financial performance through waste management program.
\end{abstract}

Keywords: Environmental awareness, environmental compliance, environmental commitment, waste management, capacity building, corporate financial performance.

\section{INTRODUCTION}

Managing waste in a good and right way is an absolute condition for companies. If the company does not manage its waste properly, then the risks that will be faced will be very high. Ranging from environmental destruction, the company will not be trusted by the local people, until the criminal penalties because of the company does not fulfill the principle of law compliance.

However, as a developing country, the awareness of Indonesian companies to implement good waste management program is still very low (Aloysius et al., 2012). This certainly triggers our concerns, since the demand of the company to be pro-environment is no longer an option but it is a necessity. For example, a data released by the Institute of Technology Bandung mention that there is 16.4 percent, or about 1.15 million tons of industrial waste was not reported (Statistic of Indonesian Ministry of Environment, 2006). The data that was not reported here might mean not knowing the disposal of waste 
generated by the industry. It raises the speculative assumption that the waste generated by the industry in Indonesia is discarded carelessly, like discharged into rivers or the sea, or even dumped in public landfills. Furthermore, referring to the data released by the Institute of Technology Bandung in 2009 shows that there are about 7 million tons of industrial waste generated. From the data, 49.4 percent or 4.6 million tons of waste discarded carelessly or did not follow the provisions of the $3 \mathrm{R}$ (recycle, reuse, recovery) which is a requirement from the government.

This phenomenon would be a big question, why did it happen? On one side, the government has set up and made the rules strictly. On the other hand, the world is experiencing an environmental crisis and the demands to encourage the pro-environment company to be stronger. There were many agreements between nations which aims to improve the condition of the environment such as delimitation of the greenhouse effect, pollution decrement, etc. This agreement implicates to the pro-environment company costs, so as the implication there is an effort to give incentive to pro-environment companies. The reason that most frequently appears is that the demands of companies to improve their financial performance caused them tend to do everything to reduce costs, including by managing their waste carelessly. In fact, if it is managed carelessly, then in the long term it would harm the company as described above.

Based on the phenomenon of waste management in developing countries, such as Indonesia, this research is testing the influence of awareness and legal compliance of companies towards the commitment and the desire to implement a waste management program that eventually led to the improved performance of the company. Empirical testing of waste management by the companies in Indonesia is expected to give an illustration that there are benefits that will be received by the companies if they do good waste management. Next, it will be presented sequentially for the theoretical foundation and development of hypotheses, then the research methods used, until finally the results and conclusions of this study would be explained.

\section{THEORETICAL REVIEW}

Developing countries basically also bear the potential environmental problems associated with waste, which if it is not managed properly, will cause big problems later on. For example, in developing countries, the industy with high energy usage (such as the cement industry and the industries that have factories as a place to process the products) is an integral part of the overall national industry. These industries play important roles related to the capacity of waste management and to encourage their environmental protection policies. However, the facts show in some countries, like Indonesia, these industries face some issues, such as regulatory gaps that could encourage the growth of industry, the division of waste management that is not fair, and some of the technical issues of waste management which become separated issues in doing a good waste management. However, the industry is growing in accordance with the social conditions where the industry is located. (Tsai et al., 2012) tested the industries and consumers to see if there are common interests between consumers and industries in the concerns related to environmental issues. Industry which was used as the subject of research is the toy industry. The result of the research concluded that the desire to buy toys that are environmentally friendly increases if most people already have a belief about the toy which is environmentally friendly. The 
existence of the social environment affects the concerns to community issues, including environmental issues. The phenomenon of the increase of public awareness about its environmental awareness has become an important issue. It can be seen from several studies conducted, like studies conducted by (Yakoob and Zakaria, 2013) in Penang, Malaysia, which shows that there is a positive relationship between the awareness of the importance of the environment and attitudes towards green products. Later, there were similar studies conducted by (An, 2008) in China, and (Garcia et al., 2008) in Indonesia.

The condition of society in developing countries contains a lot of variety of interests, including its relation to the awareness of environmental issues. On the one hand, there are still many people who look at issues of waste as something simple and do not need to be contemplated. On the other hand, the influence of the developed countries is very dominant. For example, rules on eco-labeling which demand furniture companies to prove that the raw materials are sourced from woodlands which are managed properly, can be said that it is the environmental impact of developed countries that cannot be avoided by developing countries, including the industry players in there.

In developing countries the variations groups which have interests with the company is the focus of a separated issue that must be faced by the industry in conducting waste management practices. Industrial environmental conditions in developing countries become the basic of the studies of waste management strategy which is based on stakeholder theory. This theory identifies the groups which are interested in the organization both from within the organization (employees, managers, and owners) and from outside the organization (suppliers, government, customer, etc.) (Donaldson and Preston, 1995; Hasnas, 2013). Associated with waste management, stakeholder theory provides the basis that the company concerned with the perception which is built by the community about it (Freeman, 1984). However the conditions faced by the companies, although sometimes it is very hard and heavy, they will try to match themselves with the condition of their stakeholders.

The growth of the industry's concerns to environmental issues does not exist in an instant. There is a process to be followed to reach the level of adoption of good environmental management. (Hendry and Vesilind, 2005) used the theory of moral development proposed by Kohlberg to identify ethical growth stage companies in relation to the accommodation process of environmental issues in order to create a friendly business environment. They stated that there are three things that must be considered in the context of the growth stage in the ethical environment. First, it is the concerns which are focused on legal issues. Secondly, it is the concerns which are focused on financial issues. Thirdly, it is the concerns that are focused on ethical issues. This study examines the growth of the ethical stance of companies in environmental management, especially in industrial waste.

Corporate Environmental Awareness. (Winsemius and Guntram, 2002) developed four stages of organizational responses typology towards the environmental concerns. These stages are reactive, functional, integrated, and proactive. Reactive response is something to endure and the reluctance to change. Organizations that are at this stage react to the new regulatory environment and try to maintain the existing conditions. While functional response more or less is in defense and more effective in setting the organization target to adapt to environmental standards with greater economic benefits. Integrative responses are always pursued by the organization that is currently leading in the environmental aspect. Those organizations are trying to recognize and respond to pressure from 
stakeholders, including the government, non-governmental organizations, and customers. The companies strive to integrate environmental concerns into all policy strategies at all levels of the organization. Finally, proactive response is a response that appears as a reaction to a fundamental change that is motivated by environmental vision that guides the management, staff, and activities. In this case, the organizations put the value of stakeholder on the harmonization of environmental and sustainability efforts. Because of that, the concern is if there is the awareness of environmental conditions, then it will expedite the adoption of environmental management including the companies' waste management.

Looking at the current state of environmental awareness and the policy in Indonesia, the sustainability of the organization moves gradually in a large scale carried out by industry players. In 2009, the manifestation of electronic waste management system has been issued by the Indonesian government. This system is a signal that the authorities are trying seriously and accurately in tracing the calculations of garbage. These regulatory changes are needed, and generate positive things. However, this condition can only intervene in the process of understanding the environment from the external side. There are other things that must be considered, such as knowledge, skills, experience and adherence to regulations. There is a wide range of coverage in order to achieve a decision which is in favor of the adoption of environmental regulations.

The most fundamental thing is the awareness of the importance and the meaning of the environment. The awareness of the environment that exists in the organization and the players will increase the concerns to environmental aspects. (Yaacob and Zakaria, 2013) tried to test the level of public awareness in Kuantan, Pahang, Malaysia about the awareness of environmentally friendly products. The result concluded that people who have awareness of environmentally friendly products directed their stance on aspects related to the environment. In the context of industry players, the awareness of environmental conditions will lead to a stronger commitment on the environmental aspects. Based on that argument, the hypothesis is as follows.

H1: The awareness of companies about the environment will improve the companies' environmental commitment.

Companies that have environmental awareness will strive to realize that there is a boost in the company's internal corporate programs. (Hendry and Vesilind, 2005; 2010) attempted to develop a model of ethical growth of companies related to environmental concerns. The ethical growth of the companies begins when they are growing their environmental awareness. Environmental awareness will support the establishment of good waste management program as the consequences to give shape their awareness. Moreover, the programs that are environmentally friendly can benefit the company. Based on that argument, the hypothesis is as follows.

H2: The companies' environmental awareness will influence the company's waste management program.

Fulfillment of Companies' Legal Obligations Related to Environmental Issues. The subject of compliance with environmental legal obligations as part of regulatory compliance 
required in industrial waste management area has been examined from the perspective of the generalization of organization waste and also from the perspective of waste management of the organization. (Stafford, 2007) as well as (Aloysius and Daihani, 2011) demonstrated the empirical relationship that increasing waste management by an organization is characterized by its facilities, waste management market, and the organization's compliance with waste regulations. It occurs in the context of the waste management market maturity in the United States. The results showed an increase in the compliance towards the regulations in waste management.

In developed countries, America has given the challenge of how regulation can encourage changes in technology and waste management. (Macauley, 2009) discussed these changes and challenges have emerged from the experience of the Resource Conservation and Recovery Act of 1976 (known as RCRA). This Charter leads to the growth and development of land for waste management. During this period the movement of waste management changed from the constraints to be an experience for the providers of waste management services. What happened in America has provided learning opportunities that may also emerge in Indonesia. This learning opportunity gives the message that compliance would lead to a commitment to focus on the environment. Based on this argument, the hypothesis is as follows.

H3: The compliance with environmental regulations will increase the commitment of the company's waste management.

Compliance with regulations requires a demonstration of the practical aspects of the company's operations to be performed by the company. (Westerlund, 2013) cited what was said by Kiron et al., that the programs run by the company in order to create a friendly business environment will provide at least five benefits to the company, namely: market benefits, financial benefits, the benefits of the technology, the benefits of compliance with the law, and the benefit of the parties associated with the company. Then, (Hendry and Vesilind, 2005) revealed that the ethical growth of the company at an early stage is closely related to legal issues. It will encourage companies to have compliance with applicable regulations outlined in the programs. The application of waste management is realized through a company's waste management program. Based on these arguments, the hypothesis is as follows.

H4: The compliance of law with company's environment will affect the company's waste management program.

The Role of the Company's Capacity in Waste Management. The achievement of the development of waste management requires capacity as a part of the waste management infrastructure. Waste management facilitates waste operator. (Evans et al., 2009) tried to observe the audit facilitation practices on waste management. The study showed the existence of a larger facility that should be focused by the regulations in conditioning an audit of waste management.

In developing countries, the issue shows the capacity of the facilities owned by companies associated to waste management which is wanted to do. The commitment of waste management which is formed due to awareness and compliance towards the 
environmental regulations lead to a commitment to the environment is faced by the presence or absence of capacity owned by the company to hold a waste management program. (Wood and Williamson, 2010) tried to uncover the capacity issue for companies by using ecological modernization theory. They concluded that the capacity of the company is the tangible manifestation of the company's commitment. The companies which are committed to environmental issues will increase its capacity to support the creation of good environmental management. Based on these arguments, the hypothesis is as follows.

H5: The effects of environmental management commitment towards waste management programs will be strengthened by the capacity owned by the company.

The Implication of Waste Management. A good waste management in a company will direct the company to enjoy the long-term benefits (Epstein, 1996). (Robinson and Stubberrud, 2013) examined the impact of innovation on the activities of small and medium enterprises and large enterprises in Germany related to environmental issues. The results of the study showed a reduction in macro energy use arising from activities to focus their concerns on the environmental issues. The effort that is most often done to lead to the management of environmental problems is to reduce the use of energy.

Not only towards the physical condition, companies that perform environmental management including good waste management will also be able to enjoy the benefits in the form of benefits that will be accepted, like market benefits, financial benefits, the benefits of innovation, the benefits of regulatory compliance, and benefit from the parties related to the company (Westerlund, 2013). One of the interesting ones is related to the company's financial performance. Many thoughts stated that a focus on environmental issues will make extravagance within the company. Various refutations about those statements are proposed by (Westerlund, 2013), (Sharma and Gadene, 2014), and (Blazovich et al., 2013). (Weseterlund, 2013) revealed that there are many advantages that can be enjoyed by the company if the implementing programs are based on good environmental management. Then, (Blazovich et al., 2013) concluded from a study that had been done that the company which is friendly to the environment through its programs will enjoy two advantages, namely their financial performance and better profitability. It happens because the environment is an integral part which cannot be separated in the overall corporate management. The study from (Blazovich et al., 2013) was strengthened by (Sharma and Gadene, 2014), which reported an increase in the signal of increased concerns towards companies that implement green products. Based on the arguments, the hypothesis is as follows.

H6: The companies' waste management programs affect the company's financial performance.

\section{METHODOLOGY}

The method used to test the hypotheses in this study was survey techniques by distributing questionnaires to managers of the manufacture companies that have implemented waste management. 
Figure 1. Model Research

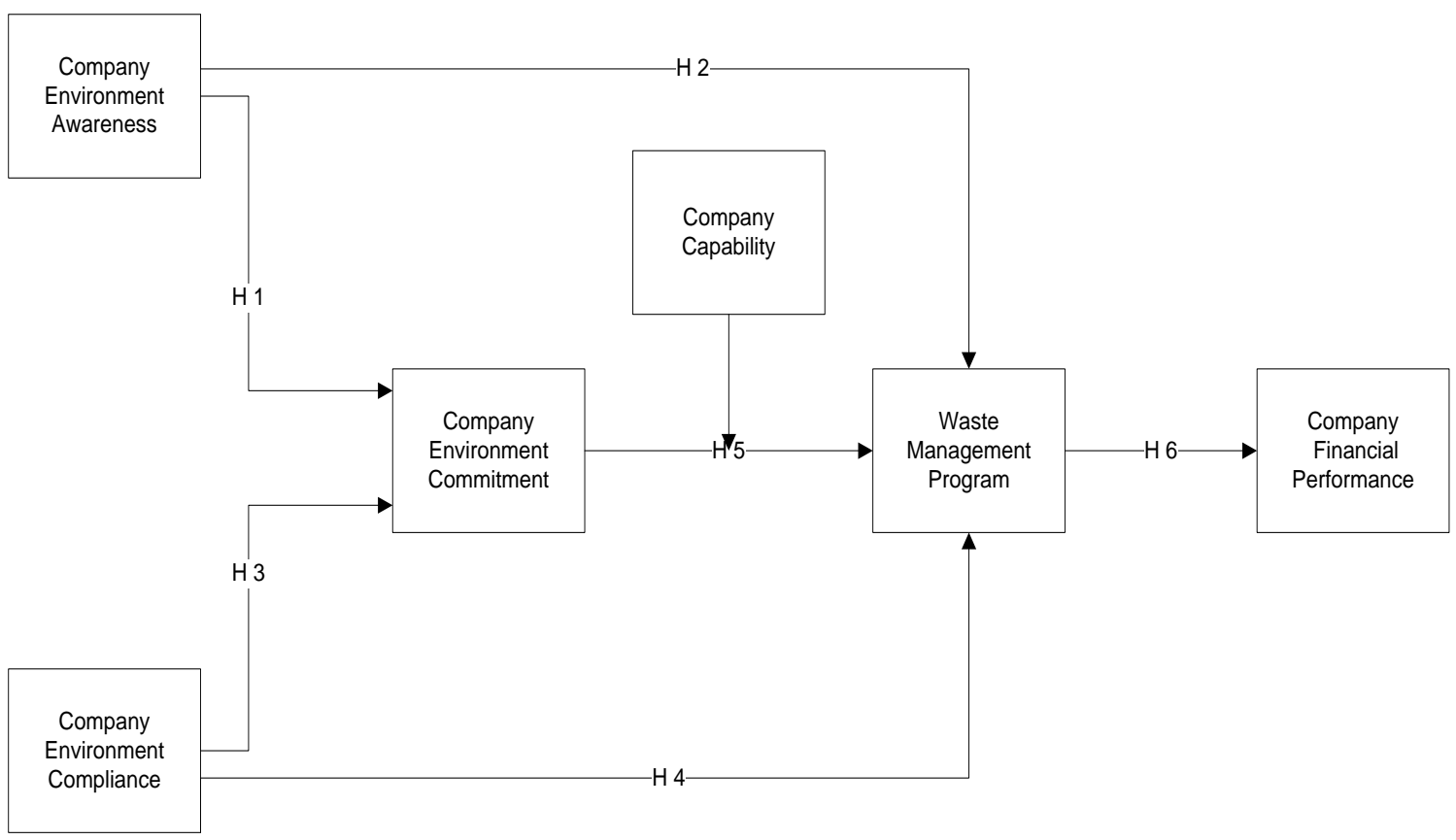

Sampling technique which was used is purposive sampling, which is a sampling technique in which the elements of the population have been chosen because of specific intentions based on the considerations of researchers (Baalbaki and Malhotra, 1999).

The considerations for selecting the samples with purposive sampling method is the manager of a manufacturing company who had worked for at least 3 years and understood the importance of waste management on the financial performance of the company. Although the data source is the managers of manufacturing companies, the unit of analysis which was aimed in this study is the manufacturing companies. The framework of analysis that would be conducted was aimed to be concluded based on the condition of manufacturing companies in Indonesia. In addition, the other criteria of samples which was taken into considerations are the companies that have implemented good waste management program.

Three years have been selected based on preliminary interviews that were conducted. Three years is the minimum period to get a complete understanding of waste management in the company. The size of the sample in the study of structural equation modeling with a minimum of 100 samples, i.e. by considering the estimated research model. The characteristics of the companies which became samples in this study are as follows. 
Table 1. The characteristics of the respondent manufacture companies

\begin{tabular}{c|l|l}
\hline $\begin{array}{c}\text { Number of } \\
\text { Company }\end{array}$ & \multicolumn{1}{c|}{ Type } & \multicolumn{1}{c}{ Size } \\
\hline 43 & Public Listed Company & Medium Size Company (100-500 billion rupiah) \\
\hline 6 & Public Listed Company & Large Company (above 500 billion rupiah) \\
\hline 37 & Family Business Company & Medium Size Company (100-500 billion rupiah) \\
\hline 14 & Start Up Company & Small Size (below 100 billion rupiah) \\
\hline
\end{tabular}

Source: (Data analysis, 2019)

Data collection technique in this research was conducted through a questionnaire by using Likert scale by making a list of questions which would be filled by the respondents to obtain data in the form of answers which would be analyzed. In this study, the instrument to measure the research variables used a Likert scale of 7 points (1-7) scale. To test the hypothesis of the study, it used an analysis tool namely Structural Equation Model (SEM) with the help of LISREL program version 8.80. SEM is a technique that combines aspects of multivariate regression and factor analysis to estimate a series of dependency relationships simultaneously (Hair et al., 1995).

Before distributing the questionnaires to 100 main respondents, we conducted pre-test towards the questionnaire to be distributed. Those questionnaires were given to 30 respondents to test the existing validity and reliability. The pre-test results showed that all instruments were valid and sufficient with minimal coefficient of 0.4. (Nunnally, 1978). Some questions that show problematic issues are based on the comments of respondents during the pre-test had been anticipated in the main idea of this research.

Measurement. The measurement of the variables used in this research is the development of some of the previous literatures. The measurement of the awareness of the company followed the ethical growth of the company proposed by (Hendry and Vesilind, 2005). Then, the measurement of the company's commitment used the measurement developed from (Stafford, 2007). Furthermore, the regulatory compliance is a measurement developed from (Westerlund, 2013) and (Wood and Williamson, 2010). Company's waste (garbage) management programs used instruments that were developed from a study conducted by (Garcia et al., 2008). Finally, the capacity and the financial performance of companies related to waste management are instruments which were developed from (Wood and Williamson, 2010) and (Robinson et al., 2013).

Reliability Testing. Reliability is an extension of the measurement results, so that those measurement results can be trusted. A measurement of instrument is said to be reliable if the results of the measurement instrument can meet the elements to be measured. In this research, awareness, compliance with laws, commitment, capability, waste management program, and the company's financial performance were measured by using KMO and MSA formula reliability measurement. Reliability test indicated that each instrument was associated with the other instruments in the same variable (Sekaran, 2003). 
Validity Testing. Testing the validity of the instruments is intended to expand the accuracy and precision of the measurement of a question item. A question item is measured in its quality as a benchmark towards the measurement on the overall questions that represents a variable measurement instrument. The purpose of validity testing is to obtain items of questions that can declare a variable function in the study conducted. In this study, factor analysis was used to measure the validity of the question items.

\section{Research Constructs}

Table 2. The Operation of Measurement and Reliability Value Scale

\begin{tabular}{l|c|c}
\hline \multicolumn{1}{c|}{ Item } & KMO & MSA \\
\hline Awareness to manage waste (a=0863) & 0837 & \\
\hline $\begin{array}{l}\text { AW1: My organization has the influence of good waste } \\
\text { management program has been in increasing the environmental } \\
\text { awareness. }\end{array}$ & & 0797 \\
\hline $\begin{array}{l}\text { AW2: My organization has the influence of good waste } \\
\text { management program has been to encourage to select } \\
\text { environmentally friendlier solutions for waste generated from its } \\
\text { operations. }\end{array}$ & \\
\hline $\begin{array}{l}\text { AW3: My organization has the influence of good waste } \\
\text { management program has been to encourage the organization to } \\
\text { improve on the management of waste generated from its operations. }\end{array}$ & & 0856 \\
\hline $\begin{array}{l}\text { AW4: My organization has to adopt the 3R (reduce, re-use, recycle / } \\
\text { recover) philosophy in the management of waste from their } \\
\text { operations. }\end{array}$ & 0856 \\
\hline $\begin{array}{l}\text { AW5: Environmental awareness is encouraging my organization to } \\
\text { cooperate with waste management companies Able to provide 3R } \\
\text { (Reuse-Recycle-Recover) solutions for our industrial waste. }\end{array}$ & & 0818 \\
\hline
\end{tabular}

Source: (Data analysis, 2019)

This research used seven constructs, namely: awareness, compliance with laws, environmental commitment, organizational strength, waste management programs, and financial performance. Each construct was measured with 3 to 5 questions which were developed from some literatures as described in the previous section. The results of the testing of validity and reliability measurement are presented in Table 2.

Variable measurement used a Likert scale with 7 points measurements from 1 (strongly disagree) to 7 (strongly agree). This scale allows the researchers to present the degree of approval or disapproval. After the distribution of questionnaires, the researchers conducted exploratory and confirmatory analysis which was also performed in this study. Exploratory Analysis of the components (varimax rotation) and reliability analysis were performed to purify the scale used. For all constructs, a dimensional structure can be found. 
Table 3. The Operation of Measurement and Reliability Value Scale

\begin{tabular}{l|l|l}
\hline \multicolumn{1}{c|}{ Item } & KMO & MSA \\
\hline Compliance in waste management $(\alpha=0.886)$ & 0835 & \\
\hline $\begin{array}{l}\text { CW1: The policies of the Ministry of Environment are } \\
\text { encouraging industries to opt for the 3Rs of waste management } \\
\text { companies providing solutions. }\end{array}$ & & 0.88 \\
\hline $\begin{array}{l}\text { CW2: The Ministry of Environment's policies are encouraging } \\
\text { new and existing waste management businesses to increase of the } \\
\text { 3Rs of waste solution capacity. }\end{array}$ & & 0881 \\
\hline $\begin{array}{l}\text { CW3: The Ministry of Environment's policies are encouraging } \\
\text { businesses to improve waste management in compliance to } \\
\text { regulations. }\end{array}$ & & \\
\hline $\begin{array}{l}\text { Commitment to apply good waste management program }(\alpha= \\
\text { 0.800) }\end{array}$ & \multirow{2}{c}{0813} & \\
\hline $\begin{array}{l}\text { CO1: My organization has a continuous effort to management of } \\
\text { waste in a way the fulfills all the regulatory requirements. }\end{array}$ & & 0.81 \\
\hline $\begin{array}{l}\text { CO2: My organization has a continuous effort to reduce waste } \\
\text { with clear targets in place. }\end{array}$ & & 0798 \\
\hline $\begin{array}{l}\text { CO3: My organization has committed to Achieve a green rating or } \\
\text { better waste management program. }\end{array}$ & & 0734 \\
\hline $\begin{array}{l}\text { CO4: My organization has committed to use the 3Rs of waste } \\
\text { management solutions wherever possible. }\end{array}$ & & 0731 \\
\hline $\begin{array}{l}\text { CO5 My organization has committed reduce or avoid using Non } \\
\text { 3Rs of waste management solutions }\end{array}$ & & 0.76 \\
\hline
\end{tabular}

Source: (Data analysis, 2019)

A confirmation factor analysis (CFA) was performed by using LISREL 8.8 with estimation of maximum-likelihood (ML) (Joreskog and Sorbom, 1993). The assessment of the model used multiple suitability index. The index used is: Goodness-of-Fit Index, Root Mean Square Error of Approximation (RMSEA), normed Fit Index (NFI), and Comparative Fit Index (CFI). The standardized data was used for all sub data. Standardization process eliminated bias in some of the variables used in the analysis (Hair et al., 1995). Overall, compliance of the index shows that the CFA model is consistent with the data. 
Table 4. The Operation of Measurement and Reliability Value Scale

\begin{tabular}{l|l|l}
\hline \multicolumn{1}{c|}{ Item } & KMO & MSA \\
\hline Capability to run a good waste management $(\alpha=0662)$ & 0603 & \\
\hline $\begin{array}{l}\text { CA1: My organization is capable to apply the 3Rs of waste } \\
\text { management programs for our waste. }\end{array}$ & & 0833 \\
\hline $\begin{array}{l}\text { CA2: My organization will do our best to apply the 3Rs of waste } \\
\text { management program }\end{array}$ & & 0.75 \\
\hline $\begin{array}{l}\text { CA3: My organization will hire someone who understand how to } \\
\text { apply the 3Rs of waste management program if it is needed }\end{array}$ & & 0783 \\
\hline $\begin{array}{l}\text { CA4: My organization is capable to follow international standards } \\
\text { of waste management solution }\end{array}$ & & 0833 \\
\hline Waste management program $(\alpha=0763)$ & 0812 & \\
\hline $\begin{array}{l}\text { WM1 My organization always seach for the newest technology in } \\
\text { waste management programs to gain better waste solution }\end{array}$ & & 0805 \\
\hline $\begin{array}{l}\text { WM2 My organization always wants to adapt the newest } \\
\text { technology in waste management program Although it is expensive }\end{array}$ & & 0778 \\
\hline $\begin{array}{l}\text { WM3 Our Board of Directors will always support the newest } \\
\text { technology in waste management program as long as it is }\end{array}$ & & \\
achievable & 0769 & \\
\hline Corporate Financial Performance ( $\alpha=0745)$ & & 0773 \\
\hline $\begin{array}{l}\text { CF1 We believe that by applying good waste management } \\
\text { program will finally cost our Decrease in total }\end{array}$ & \\
\hline $\begin{array}{l}\text { CF2 We will take the risk of spending higher cost of managing } \\
\text { waste as long as we can get a better rating in waste management } \\
\text { program }\end{array}$ & & 0835 \\
\hline $\begin{array}{l}\text { CF3 We believe that not managing waste properly will cost more } \\
\text { in the future }\end{array}$ & & \\
\hline Source: (Data analysis, 2019$)$ & & \\
\hline
\end{tabular}

Source: (Data analysis, 2019)

Variance Bias Method. When a questionnaire to assess yourself used, the variance bias problems can be increased (Podsakoff et al., 2003). This study used common method variance (CMV) testing, which would help to identify the variables that exist because of measurement error. The urgency of this issue may appear on the independent and dependent variables. To solve this problem, some of the statistical techniques were used. Investigations of measurement techniques were developed to be careful with all the possibilities that could occur. All parts of the questionnaire could be clearly identified and the information could be given about the nature of the variables measured. 
Table 5. Model Indicators

\begin{tabular}{l|c|l}
\hline \multirow{2}{*}{ Indicators } & \multicolumn{2}{|}{} \\
\cline { 2 - 3 } & Value & Interpretation \\
\hline GFI & 0.85 & marginal Fit \\
\hline RMSEA & 0058 & Good Fit \\
\hline NFI & 0.84 & marginal Fit \\
\hline CFI & 0.93 & Good Fit \\
\hline P value & 0 & Good Fit \\
\hline standardized & & \\
RMR & 0036 & Good Fit \\
\hline \multicolumn{2}{|l}{ Source: (Da }
\end{tabular}

Source: (Data analysis, 2019)

Goodness of Fit Index (GFI) shows that 0.85 score has an inclination to 1.0 that was the conformity standard of a model. The Root Mean Square Error of Approximation (RMSEA) has a smaller score than 0.08 that shows if a model shows a close fit model that shows if that model could be accepted. Comparative Fit Index (CFI) shows that the score over 0.9. Without calculating the sample size, this model has a comparative advantages than the other similar models. Finally with the $\mathrm{p}$ value 0.00 , this model has an obvious good internal validity.

Analysis. The data shows that the hypotheses are supported. Companies that have high awareness towards the waste management will have higher commitment. It proves that awareness is important as an antecedentof formation of commitment. This is consistent with a research done by Richa and Sarkar (2014) that found that awareness is important in the formation of commitment. This finding underlined that the company's awareness about the importance of managing waste properly should be raised. Once they have an awareness of the importance of this matter, they will be committed to manage their waste properly.

Table 6. Hypotheses testing

\begin{tabular}{|c|c|c|c|}
\hline Hypothesis & Hypothesis Statements & t-value & $\begin{array}{l}\text { Supported / } \\
\text { Not Supported }\end{array}$ \\
\hline $\mathrm{H} 1$ & $\begin{array}{l}\text { Company awareness of the environment will } \\
\text { increase of company environment commitment. }\end{array}$ & 4.63 & supported \\
\hline $\mathrm{H} 2$ & $\begin{array}{l}\text { Company environmental awareness will } \\
\text { influence the company waste management } \\
\text { program. }\end{array}$ & $3: 53$ & supported \\
\hline $\mathrm{H} 3$ & $\begin{array}{l}\text { Adherence to environmental regulations will } \\
\text { improve commitment to waste management } \\
\text { company. }\end{array}$ & 2.77 & supported \\
\hline $\mathrm{H} 4$ & $\begin{array}{l}\text { Legal adherence to environmental regulations } \\
\text { related to the company environment will }\end{array}$ & 1.60 & not Supported \\
\hline
\end{tabular}




\begin{tabular}{l|l|l|l}
\hline & $\begin{array}{l}\text { influence the company waste management } \\
\text { program. }\end{array}$ & & \\
\hline H5 & $\begin{array}{l}\text { The influence of environmental management } \\
\text { commitment towards a waste management } \\
\text { program will be reinforced with the kind of } \\
\text { capacity a company has. }\end{array}$ & -1.16 & not Supported \\
\hline H6 & $\begin{array}{l}\text { A program of waste management company has } \\
\text { an influence on company financial performance } \\
\text { work. }\end{array}$ & $3: 27$ & supported \\
\hline
\end{tabular}

Source: (Data analysis, 2019)

The second hypothesis is also supported by the states of the positive relationship between law compliance and commitment. The more a company has a desire to comply with government regulations on waste management, the higher their commitment will be. A research done by (Sharma and Gadenne, 2014) showed that there is a positive relationship between attitudes to comply with government regulation and their commitments to it. This study emphasizes on the importance of providing awareness on the need to comply with government regulations. Thus, after the company becomes obedient, then it will commit to manage its waste properly. From these results, we found that it is necessary to have regulations and law on waste management. Many of the companies which are still small companies trigger the opportunity for them not to be obedient to the law. However, if it is accompanied with strict punishments, then those companies will be serious in managing their waste. Therefore, obeying the law is the first step to good waste management, followed by other factors, such as awareness and commitment.

The results of the study also concluded that the commitments give positive influence on the willingness to apply a good waste management system. The stronger the commitment of the company or in this study is the managers who represent the company to implement a system of good waste management, the better the waste management practices. It shows that the commitment is really one of the strong driving forces for the formation of a good waste management system. The results are consistent with a research done by (Yaakob and Zakaria, 2013), who found that awareness and commitment influence the desire to create green products in Malaysia.

One interesting thing from this study is that the non-acceptance of the hypothesis that the capability to moderate the relationship between the commitment and the desire to implement a good waste management. It happened because most companies in Indonesia do not have the capability to manage their own waste. Instead, they use outsiders or outsourcing services to manage their waste. Some of these companies, for example PT. Waste Management Indonesia, PT Geocycle Indonesia, etc. Because they do not have the capability to manage the waste itself, the capability does not moderate the relationship between commitments with good waste management. Capability of the company to manage its own waste should not be held, but may involve the third parties.

The last hypothesis states that the better implementation of waste management, the higher the company's financial performance will be. This study shows that the hypothesis is supported by data. (Westerlund, 2013) in his thesis stated that green products will increase the sustainability of the company. (Blazovich et al., 2013) also found that green companies will have a positive impact on the financial performance of the company. Therefore, it is 
necessary for the company to continue to move towards green company through good waste management practices. Thus, their financial performance will increase because they can reduce their environment costs.

\section{CONCLUSION}

This study attempts to understand the link between commitment, waste management program, and financial performance. There are still many companies that are forced to manage their waste, even many of them are still doing it carelessly. They just think to comply with government regulations on waste management without understanding that the long-term commitment and proper waste management will have positive impacts on the financial performance of the company. First, customers will appreciate and buy products from the green company. Second, employees will also love and loyal in working at the companies that manage the waste properly. Thirdly, there will be no legal consequences for the violation. Therefore, it is important for companies to raise their awareness, commitment, their obedience attitude because it is an early embryo to get good financial performance.

\section{REFERENCE}

An, Zhang Xiuli. (2008). "Analysis of the Results of Environmental Performance Rating and Disclosure for Pollution Control Program in Changshu, China." College of Environmental Sciences and Engineering, Peking University, Beijing, China.

Aloysius, V., D. Umar, and Daihani. (2012). "The Growing Demand For Alternative Solutions For Industrial Waste; The Experience of Indonesia." Un publish paper.

Aloysius, V., \& Daihani, D. U. (2011). Closing The Waste Gap In Indonesia: Harnessing Industrial Waste To Prevent Pollution And Conserve Non-Renewable Resources (No. 2011/29).

Baalbaki, I. B., and N. K. Malhotra. (1993). "Marketing Management Bases For International Market Segmentation: An Alternate Look At The Standardization / Customization Debate." International Marketing Review, Vol. 10, No.1.

Blazovich, J. L., K.T. Smith, and L. M. Smith. (2013). "An Examination of Financial Performance and Risk of Environmentally Friendly 'Green' Companies." Journal of Legal, Ethical and Regulatory Issues, Vol. 16 No. 1, pp 121-134.

Day, G. S. , and Paul J. H. Schoemker. (2011). "Innovation in Uncertain Markets: 10 Lessons for Green Technologies." MIT Sloan Management Review, Vol. 52 No. 4, p.36-45.

Donaldson, T., and L. E. Prestone. (1995). "The Stakeholder Theory of the Corporation: Concepts, Evidence, and Implication." The Academy of Management Review, Vol.20, No. 1, pp. 65-91.

Epstein, M.J. (1996). "Improving Environmental Management with Full Environmental Cost Accounting." Environmental Quality Management, Autumn, pp. 11- 22.

Evans, Liu, and Stafford. (2009). "A facility-level Analysis of the Long-term Consequences of Environmental Auditing Among hazardous Waste Generators." Robert Day School Working Paper No. 2009-16. Robert Day School of Economics and Finance.

Freeman, R. E. (1984). "Strategic Management: A Stakeholder Perspective." Prentice-Hall, Englewoods Cliffs, NJ. 
Garcia, J. H., S. Afsah., And T. Stenner. (2008). "What Kind of Firms Are More Sensitive to Public Disclosure Programs for Pollution Control? The Case of Indonesian PROPER Program." Environment for Development, March.

Hasnas, J. (2013). Whither stakeholder theory? A guide for the perplexed revisited. Journal of Business Ethics, 112(1), 47-57.

Hair, J. F., Anderson R. E., R. L. Tatham and W. C. Black. (1995). "Multivariate Data Analysis, Prentice Hall." Englewood Clifft, NJ

Hendry, J. R., and P. A. Vesilind. (2005). "Ethical Motivations for Green Business and Engineering." Clean Technology Environment Policy, Vol. 7, pp. 252-258.

Hendry, J., and Vesilind, P. (2010). Ethical motivations for green business and engineering. IEEE Engineering Management Review, 2(38), 54-63.

Indonesian Ministry of Environment Statistics. (2006).

Indonesian-German Environmental Program, Centre for Research on Energy Policy, Institute Technology Bandung. (2009). "Report prepared for Public-PrivatePartnership to establish National Guidelines program for co-processing waste." Jakarta.

Joreskog, K. G., and D. Sorbom. (1993). "Latent Variable scores and Their Uses." From: http://www.ssicentral.com/lisrel/column6.html.

Macauley, M. K. (2009). "Waste Not, Want Not: Economic and Legal Challenger of Regulation-Induced Changes in Waste Technology and Management t. Resources For The Future, Discussion paper." RFF DP 09-11.By Business Size. Journal of International Business Research, Vol. 12, No. 1, pp47-56.

Ming, Tin Tzai, Min L. Cheung, S. T. Chen, and Chen H. P. (2012). "The Effect assessment of Firm Environmental Strategy and Customer Environmental conscious on Green Product Development." Environment Monitoring Asses, spring 4435-4447.

Nunnally, Jum C. (1978). "Psychometric Theory." 2 Ed. New York: McGraw-Hill.

Onkila, T., K. Joenseen, and M. Koskela. (2012). "How Corporation-Stakeholder Interaction is Reported in Environmental Issues?" Comparative Case Study of Environmental Reporting in a Financing, Transportation, and Energy Firm.

Podsakof, P. M., S. B. Mackenzie, J. Y. Lee, and H. D. Podsakof. (2003). "Common method biases in Behavioral Research: A Critical Review of the Literature and Recommended Remedies." Journal of Applied Psychology, Vol. 88, No. 5, 879-903.

Podsakoff, P. M., and D. W. Organ. (1986). "Self-reports in organizational research: Problems and prospects." Journal of Management, 12, 69-82.

Richa, and K. Sarkar. (2014). "An Elementary Approach on awareness of Green Practices: In Indian context.” Journal of Asia Entrepreneurship and Sustainability, Vol. X, issue 1, pp. 89-100.

Robinson, S., and H. A. Stubberud. (2013). "Green innovation in Germany: A Comparison By Business Size.” Journal of International Business Research, Vol. 12, No. 1, p. 47 56.

Have now, Uma. (2003). "Research methods for business: A skill building approach." 4th edition, John Wiley \& Sons.

Sharma, B., and D. Gadenne. (2014). "Consumers' attitude, green practices, demographic and social influences, and government policies: An empirical investigation of Reviews their relationships." Journal of New Business Ideas \&Trends, Vol. 12, No. 2, pp. 22-36. 
Stafford, S. L. (2007). "Can consumers enforce environmental regulations? The role of the market in hazardous waste regulation." Journal of Regulation Economy, 31: 83-107.

Tsai, M.T., Chuang L. M., S.T. Chao, and H. P. Chang. (2012). "The Effect of Firm Environmental Assessment Strategy and Customer Environmental Conscious on Green Product Development." Environment Monitoring Assessment, Springer, pp. 4435-4447.

Walker, Elizabeth A., J. Redmund, and M. Wills. (2010). "A Proposed Methodology to Promote Adoption of Green Production By Small Firms." International Journal of Business Studies, Special Edition, Vol. 18, No. 1, p. 39-48.

Westerlund, M. (2013). "Green Business Models to Change the World: How Entrepreneurs Can Ride the Wave Sustainability?" Technology Innovation Management Review, p. 54-57.

Winsemius, P., and U. Guntram. (2002). "A thousand shades of green: Sustainable strategies for competitive advantage." Earth scan Publications Ltd.

Wood, G. S., and D. Williamson. (2010). "The receptive Capacity of Firms and The Regulation of Ecological Modernization." Starting ECPR Group's Regulatory Governance. Third Biennial conference, June 17-19 at University College Dublin.

Yaacob, M. R., and A. Zakaria. (2013). "Customers Awareness, Perception, and Future Prospects of Green Products in Pahang, Malaysia." The Journal of Commerce, Vol.3, No. 2, pp. 1-10. 